\title{
The Standard of Appellate Review in Title VII Disparate-Treatment Actions
}

Title VII of the Civil Rights Act of $1964^{1}$ prohibits employers, ${ }^{2}$ employment agencies, ${ }^{3}$ labor organizations, ${ }^{4}$ and administrators of job-training programs ${ }^{5}$ from classifying or discriminating against any person with respect to employment or membership on account of the person's race, color, religion, sex, or national origin. In addition, it forbids retaliatory discrimination against any employee, member, or applicant for employment or membership who "opposed" an unlawfully discriminatory employment practice or took part in an enforcement proceeding under the Act. ${ }^{6}$ Original jurisdiction over Title VII actions ${ }^{7}$ lies in the United States district

142 U.S.C. $\$ \S 2000$ e to 2000 e-17 (1976 \& Supp. IV 1980) [hereinafter cited without cross-reference as Title VII].

2 Title VII \& 703(a), 42 U.S.C. § $2000 \mathrm{e}-2(\mathrm{a})$ (1976).

3 Id. $\S 703(\mathrm{~b}), 42$ U.S.C. $\S 2000 \mathrm{e}-2(\mathrm{~b})$ (1976).

Id. $\$ 703(\mathrm{c}), 42$ U.S.C. $\$ 2000 \mathrm{e}-2(\mathrm{c})$ (1976).

Id. $\S 703$ (d), 42 U.S.C. $\S 2000 \mathrm{e}-2(\mathrm{~d})$ (1976).

- Id. § 704(a), 42 U.S.C. $\$ 2000 \mathrm{e}-3(\mathrm{a})$ (1976).

7 A person claiming to be aggrieved by an unlawful employment practice may file a charge with the Equal Employment Opportunity Commission ("EEOC"), see id. § 705, 42 U.S.C. § 2000e-4 (1976 \& Supp. V 1981) (prescribing the composition of the EEOC), within 180 days after an allegedly discriminatory incident, $i d$. $\$ 706(\mathrm{e}), 42$ U.S.C. $\$ 2000 \mathrm{e}-5(\mathrm{e})$ (1976). However, if the complaint arises in a jurisdiction maintaining a state or local agency authorized to grant relief from unlawful employment practices, the complaint must first be made before that agency. Id. \& 706(c), 42 U.S.C. $\$ 2000 \mathrm{e}-5$ (c) (1976). In that event, the deadline for filing with the EEOC extends to the earlier of 300 days after the initial incident or 30 days after the local agency terminates its investigation of the complaint. Id. $\S 706(\mathrm{e})$, 42 U.S.C. $\S 2000 \mathrm{e}-5(\mathrm{e})(1976)$.

The EEOC must serve notice of a complaint upon the respondent within 10 days of receiving it and must thereafter promptly investigate the validity of the complaint. Id. $\S$ 706(b), 42 U.S.C. $\$ 2000 \mathrm{e}-5$ (b) (1976). The EEOC will dismiss the charge if the investigation discloses no "reasonable cause to believe that [it] is true," id.; otherwise, the EEOC must "endeavor to eliminate any . . . unlawful employment practice by informal methods of conference, conciliation, and persuasion," id. The EEOC has no enforcement powers, but if, within 30 days after a charge is filed, it has not obtained a conciliation agreement, it may commence a civil action against any private respondent. $I d$. $\S 706(\mathrm{f})(1), 42$ U.S.C. $\$ 2000 \mathrm{e}-$ $5(f)(1)$ (1976). If the respondent is a political unit or agency, the EEOC must refer the complaint to the United States Attorney General for prosecution. Id. Moreover, if the EEOC has neither commenced an action nor reached a settlement satisfactory to the complainant within 180 days after the filing of the charge, it must issue a notice (commonly called a "right-to-sue letter") to the complainant, advising him of his right to commence a private action against the respondent within 90 days of receiving the notice. Id. "If the court finds that the respondent has intentionally engaged in or is intentionally engaging in an 
courts, ${ }^{8}$ whose judgments are appealable to the United States courts of appeals. ${ }^{9}$

Title VII actions fall into two principal categories: those premised on the "disparate treatment" of an individual or class and those based on the "disparate impact" of a challenged employment practice. ${ }^{10}$ This comment confines itself to consideration of disparate-treatment actions. In a series of cases, commencing with $M c$ Donnell Douglas Corp. v. Green ${ }^{11}$ and culminating in Texas Department of Community Affairs v. Burdine, ${ }^{12}$ the Supreme Court developed a procedure frequently used to prove discrimination in disparate-treatment actions. ${ }^{13}$ Under this procedure, a series of intermediate showings by the parties may create and rebut a presumption of discriminatory intent; ${ }^{14}$ this comment will consider the standard of review appropriate to a trial court's determination that such showings have or have not been made.

Although there exists a substantial literature on the conduct

unlawful employment practice charged in the complaint," $i d . \S 706(\mathrm{~g}), 42$ U.S.C. $\S 2000 \mathrm{e}-$ 5(g) (1976), it may award the complainant appropriate equitable relief, which may include reinstatement or hiring with back pay and an injunction forbidding the respondent to persist in the discriminatory practice. Id.

Title VII, § 706(f)(3), 42 U.S.C. § 2000e-5(f)(3) (1976).

- Id. § 706(j), 42 U.S.C. § 2000e-5(j) (1976).

10 See, e.g., International Bhd. of Teamsters v. United States, 431 U.S. 324, 355 n.15 (1977) ("Claims of disparate treatment may be distinguished from claims that stress 'disparate impact." "). In a disparate-treatment action, the plaintiff claims that the defendant "simply treats some people less favorably than others because of their race, color, religion, sex, or national origin." Id. In order to establish a defendant's liability under a theory of disparate treatment, "[p]roof of [the defendant's] discriminatory motive is critical, although it can in some situations be inferred from the mere fact of differences in treatment." Id.

In a disparate-impact action, the defendant's lack of discriminatory motive is irrelevant. Id. The plaintiff usually establishes the defendant's liability by proving that an employment practice not compelled by the exigencies of the employer's business has a statistically disproportionate adverse impact on a particular minority group. E.g., Albemarle Paper Co. v. Moody, 422 U.S. 405 (1977). The seminal case on disparate impact is Griggs v. Duke Power Co., 401 U.S. 424 (1971), where the Court held that Title VII proscribes "practices ... neutral on their face, and even neutral in terms of intent . . . if they operate to 'freeze' the status quo of prior discriminatory employment practices," $i d$. at 430 , or if they are "fair in form, but discriminatory in operation," id. at 431.

${ }^{21} 411$ U.S. 792 (1973).

12450 U.S. 248 (1981); see also Board of Trustees of Keene State College v. Sweeney, 439 U.S. 24 (1978); Furnco Constr. Corp. v. Waters, 438 U.S. 567 (1978).

1s Burdine, 450 U.S. at 252.53 (quoted in text accompanying note 71 infra); see B. Schlei \& P. Grossman, Employment Discrimination Law 311-13 (Supp. 1979) ("The 'order and allocation of proof' defined in McDonnell Douglas, refined in Furnco, has continued to be widely applied to individual cases alleging disparate treatment in hiring, discharge, discipline, promotion, transfer, layoff, retaliation, and compensation." (footnotes omitted)).

it See infra notes 69-71 and accompanying text. 
of disparate-treatment actions at trial, ${ }^{15}$ little commentary has been devoted to the standard that should govern appellate review of a trial court's findings. ${ }^{16}$ The choice of a proper standard depends on the appropriate characterization of the trial court's findings on the questions established by the McDonnell Douglas framework as findings of fact or as mixed findings of law and fact. If the former, rule 52(a) of the Federal Rules of Civil Procedure ${ }^{17}$ requires that the findings cannot be overturned on appeal unless clearly erroneous; if the latter, rule 52(a) may not be applicable, and the trial court's findings, like questions of law, may be freely reviewable..$^{18}$ In Pullman-Standard v. Swint, ${ }^{19}$ however, the Supreme Court recently held that a trial court's finding that the employer acted without discriminatory intent in operating a seniority system was a pure finding of fact, and hence, under rule 52(a), could be set aside on appeal only if clearly erroneous. ${ }^{20}$ The Court

15 E.g., Belton, Burdens of Pleading and Proof in Discrimination Cases: Toward a Theory of Procedural Justice, 34 VAND. L. Rev. 1205 (1981); Furnish, Path Through the Maze: Disparate Impact and Disparate Treatment Under Title VII of the Civil Rights Act of 1964 After Beazer and Burdine, 23 B.C.L. REv. 419 (1982); Note, Evidentiary Burden of Proof in Title VII Employment Discrimination Cases: Texas Department of Community Affairs v. Burdine, 24 How. L.J. 333 (1981); Note, Texas Dep't of Community Affairs v. Burdine: The Procedural Subversion of Griggs v. Duke Power Co.?, 17 NEw Eng. L. Rev. 999 (1982); Note, Civil Rights: Defendant's Burden of Proof in Title VII Disparate Treatment Cases, 21 WashBuRN L.J. 143 (1981).

16 A number of recent commentators have examined a perceived tendency of appellate courts to substitute their own findings of fact for those of the trial court. Compare Nangle, The Ever Widening Scope of Fact Review in Federal Appellate Courts-Is the "Clearly Erroneous Rule" Being Avoided?, 59 WAsH. U.L.Q. 409 (1981), and Note, Federal Rule of Civil Procedure 52(a) and the Scope of Appellate Fact Review: Has Application of the Clearly Erroneous Rule Been Clearly Erroneous?, 52 ST. JoHN's L. REv. 68 (1977) (arguing against appellate courts' power to substitute findings of fact) with Godbold, Fact Finding By Appellate Courts-An Available and Appropriate Power, 12 Cum. L. Rev. 365 (1982) (arguing in favor of appellate courts' power to make additional findings of fact, even to the point of receiving evidence not in the record). None of these commentators makes any specific reference to Title VII actions.

17 "Findings of fact shall not be set aside unless clearly erroneous . . . ." FED. R. Crv. P. 52(a); see infra notes 36-53 and accompanying text (discussing the circuits' division). A finding of fact is "clearly erroneous" under rule 52(a) when, "although there is evidence to support it, the reviewing court on the entire evidence is left with the definite and firm conviction that a mistake has been committed." United States v. United States Gypsum Co., 333 U.S. 364, 395 (1948). For a general discussion of rule 52(a), see Nangle, supra note 16, at 413-48.

18 The standard employed may be dispositive on appeal. See, e.g., Robbins v. WhiteWilson Med. Clinic, Inc., 660 F.2d 1064 (5th Cir. 1981) (reversing the trial court's judgment for the defendant after free review of challenged factual finding), vacated and remanded, 456 U.S. 969, rev'd on remand, 682 F.2d 503 (5th Cir. 1982) (affirming the trial court's judgment under the clearly erroneous standard).

10 456 U.S. 273 (1982).

${ }^{20}$ Id. at 290 (" $[\mathrm{A}]$ court of appeals may only reverse a district court's finding of dis- 
seemed to disapprove the free-reviewability standard for findings in disparate-treatment actions; ${ }^{21}$ however, it specifically declined to pass upon the general applicability of rule 52(a) to so-called mixed questions of law and fact. ${ }^{22}$

This comment describes the distinctions among questions of law, questions of fact, and mixed questions of law and fact, as well as the standard of appellate review proper to each. It then argues that Pullman-Standard does not require that every finding going to proof of discrimination in disparate-treatment actions be treated as a finding of fact. In particular, several of the steps of the presumptive mode of proof established in McDonnell Douglas involve mixed questions. ${ }^{23}$ The comment then argues that free review of mixed questions in Title VII actions is compatible with the proper roles of trial and appellate courts. It concludes that free appellate review will compel courts of appeals to delineate increasingly precise standards to guide district courts called upon to determine the legal significance of discrete fact clusters.

\section{The Standard of Review Proper to Disparate-Treatment AcTIONS}

A. Questions of Fact, Questions of Law, and Mixed Questions of Law and Fact

A determination that $A$ struck $B$ is clearly a pure question of fact; a determination that $A$ is liable in tort to $B$ is just as clearly a question of law. Mixed questions of law and fact, which have been defined as "issues in a law suit involv[ing] elements of both law and fact,"24 complicate this dichotomy. Many courts have recognized such issues where the legal categorization of a fact may determine the outcome of a case. ${ }^{25}$ For example, a determination that

criminatory intent if it concludes that the finding is clearly erroneous under rule 52(a).").

${ }^{21}$ See Lincoln v. Board of Regents of the Univ. Sys., 697 F.2d 928, 940 \& nn.14-15 (11th Cir. 1983) (construing Pullman-Standard to reject the free reviewability standard); Chaline v. KCOH, Inc., 693 F.2d 477, 480 \& n.3 (5th Cir. 1982) (same); Robino v. Norton, 682 F.2d 192, 195 (8th Cir. 1982) (same); Mitchell v. M.D. Anderson Hosp., 679 F.2d 88, 8990 (5th Cir. 1982) (same).

${ }^{22} 456$ U.S. 289 n.19 ("We need not . . . address the much-mooted issue of the applicability of the rule 52(a) standard to mixed questions of law and fact . . . ."); see infra notes 24-35 and accompanying text (discussing the meaning of "mixed question").

${ }^{23}$ This comment argues that a finding of the existence of a prima facie case or a finding that defendants' rebuttal is a pretext may, see infra notes 72-84, 91-106 and accompanying text, and a finding of rebuttal always, see infra notes 85-90 and accompanying text, involve mixed questions.

24 C. Wright \& A. Miller, 9 Federal Practice and Procedure § 2589, at 753 (1971).

${ }^{25}$ E.g., antitrust violations, bankruptcy, contracts, copyright, and taxation. See id. 
certain defendants conspired to violate the antitrust laws, while seemingly factual, also requires the application of a legal standard to the issue under consideration-namely, whether the acts committed by the defendants legally constitute a conspiracy. ${ }^{26}$

A challenge to a trial court's finding upon a mixed question requires an appellate court to decide whether the proven or admitted facts are sufficient to support the conclusion of law drawn from them. Because it assumes the trial court's findings as to the historical facts and concerns itself only with whether those facts meet some legal standard, an appellate court's review of mixed questions should be conducted under the free-reviewability standard.

The distinction between questions of fact and questions of law is fundamental to the proper allocation of judicial functions between trial and appellate courts. A trial court, having the opportunity to observe the demeanor and judge the credibility of witnesses, is usually better able to weigh the evidence than is an appellate court whose view is confined to the record on appeal. ${ }^{27}$ Hence, under rule 52(a) of the Federal Rules of Civil Procedure, a trial court's findings of fact, if not clearly erroneous, bind appellate tribunals. ${ }^{28}$ Appellate courts, on the other hand, are more authoritative expositors of the law than trial courts and may freely set aside conclusions of law drawn by the trial court. ${ }^{29}$

Rule 52(a) is premised on this division of labor between the two levels of courts, ${ }^{30}$ and free review of mixed questions of law and fact is fully consistent with this apportionment. Rule 52(a) also requires trial courts, in all actions tried without a jury or with an advisory jury, to "find the facts specially and state separately [their] conclusions of law thereon."31 Inasmuch as free review of

$\S 2589$, at 754 \& nn.56-60.

28 See United States v. General Motors Corp., 384 U.S. 127, 141 n.16 (1966) (holding that such an issue is a mixed question and may be freely reviewed).

${ }^{27}$ E.g., Zenith Radio Corp. v. Hazeltine Research, Inc., 395 U.S. 100, 123 (1969).

${ }^{28}$ See, e.g., Gay v. Waiters' \& Dairy Lunchmen's Union, Local 30, 694 F.2d 531, 545 n.13 (9th Cir. 1982) ("The district court's findings of fact are subject to the limited clearly erroneous standard of review because the trial court, not the court of appeals, is best equipped to make factual determinations."). However, if a factual finding depends entirely upon written evidence that an appellate court may evaluate as readily as the trial court, appellate deference may be reduced. Id. ("We have, therefore, generally limited application of the clearly erroneous standard to situations in which we should appropriately defer to the district judge's superior fact-finding expertise.").

20 See, e.g., United States v. Mississippi Valley Generating Co., 364 U.S. 520, 526 (1961); see generally C. Wright \& A. Miller, supra note 24, § 2588, at 750.

so See, e.g., Gay v. Waiters' \& Dairy Lunchmen's Union, Local 30, 694 F.2d 531, 545 n.13 (9th Cir. 1982).

${ }^{31}$ Fed. R. Crv. P. 52(a). 
mixed questions obliges appellate courts to separate purely factual findings from conclusions about their legal significance, it thus complements the policy of rule 52(a). By applying the free review standard to mixed questions, appellate courts give trial courts an incentive to keep their factual findings and legal conclusions separate in order to concentrate the attention of the reviewing courts on the latter.

Substantial authority supports the free reviewability of mixed questions. ${ }^{32}$ For example, in Baumgartner $v$. United States, ${ }^{33}$ the Supreme Court refused to hold itself bound by the trial court's finding that the petitioner's oath of allegiance to the United States in a naturalization proceeding was fraudulent. ${ }^{34}$ Likewise, in a series of federal habeas corpus petitions brought by state prison inmates under capital sentences, the Fifth and Eleventh Circuits have repeatedly held that the question whether defendants received effective assistance of counsel at trial is freely reviewable on appeal..$^{35}$

\section{B. Standards of Review in Title VII Cases}

1. Cases prior to Pullman-Standard. Courts deciding Title VII cases have been inconsistent in differentiating among questions of fact, questions of law, and mixed questions of fact and law. Prior to the Supreme Court's decision in Pullman-Standard v. Swint, ${ }^{36}$ the federal circuits were divided on the proper standard of review for findings of discrimination in disparate-treatment cases. The First, ${ }^{37}$ Second, ${ }^{38}$ Third, ${ }^{39}$ Fourth, ${ }^{40}$ Ninth, ${ }^{41}$ and Tenth ${ }^{42}$ Circuits

${ }^{32}$ See cases cited at C. WRIGHT \& A. MILLER, supra note $24, \S 2589$, at 753 \& n.55 (1971 \& Supp. 1982).

${ }^{33} 322$ U.S. 665 (1944); see Pullman-Standard, 456 U.S. at 286 n.16.

34 Baumgartner, 322 U.S. at 671-72.

${ }^{38}$ E.g., Washington v. Watkins, 655 F.2d 1348 (5th Cir. 1981). In Washington, the Fifth Circuit noted that while ineffective assistance claims are necessarily founded on allegations of "basic, primary, or historical facts," id. at 1351 (quoting Townsend v. Sain, 372 U.S. 293, 309 n.6 (1963) (quoting Brown v. Allen, 344 U.S. 443, 506 (1953))), and require "the application of principles of federal law" $i d$. at 1348, to those facts. Accord Proffitt v. Wainwright, 685 F.2d 1227, 1247 (11th Cir. 1982); Barrientos v. United States, 668 F.2d 838, 841 (5th Cir. 1982).

${ }^{38} 456$ U.S. 273 (1982).

${ }^{37}$ E.g., Manning v. Trustee of Tufts College, 613 F.2d 1200, 1203 (1st Cir. 1980); Sweeney v. Board of Trustees of Keene State College, 604 F.2d 106, 109 n.2 (1st Cir.), cert. denied, 444 U.S. 1045 (1979).

${ }^{38}$ E.g., EEOC v. Local 28, Sheet Metal Workers Int'l Ass'n, 532 F.2d 821, 827 (2d Cir. 1976).

${ }^{39}$ E.g., Jackson v. United States Steel Corp., 625 F.2d 436 (3d Cir. 1980); Kunda v. Muhlenberg College, 621 F.2d 532, 544 (3d Cir. 1980). 
had held that a district court's finding that a Title VII defendant had engaged in unlawful discrimination, like findings of fact in general, must be honored by a court of appeals unless clearly erroneous. By contrast, the Fifth Circuit, ${ }^{43}$ followed by the Sixth, ${ }^{44}$ Seventh, ${ }^{45}$ Eighth, ${ }^{46}$ and District of Columbia ${ }^{47}$ Circuits, had distinguished "subsidiary" facts, found by direct examination of the evidence, from "ultimate" facts, dispositive of the action in which they were found, and held the latter freely reviewable. Discrimination, according to the Fifth Circuit's opinion in Causey v. Ford Motor Co.,8 "[a]lthough . . . essentially a question of fact[,] . . . is, at the same time, the ultimate issue for resolution in [a Title VII] case, being expressly proscribed by 42 U.S.C.[] § 2000e-2(a)"49 and accordingly, an ultimate fact. These circuits, while holding themselves bound by the trial court's findings of subsidiary fact that were not clearly erroneous, conducted independent analyses of whether the subsidiary facts so upheld warranted the finding of discrimination.

These differing standards of review led to anomalous results. In the First Circuit, a judgment based on a trial court's conclusory finding that a Title VII plaintiff "proved to [the court's] satisfaction that the basic reason for the failure to promote her was because of her sex"so was affirmed on appeal after the finding was

10 Smith v. University of N.C., 632 F.2d 316, 341 (4th Cir. 1980).

11 E.g., Piva v. Xerox Corp., 654 F.2d 591, 594 \& n.1 (9th Cir. 1981); Fernandez v. Wynn Oil Co., 653 F.2d 1273, 1275 (9th Cir. 1981); Golden v. Local 55, Int'l Ass'n of Firefighters, 633 F.2d 817, 820 (9th Cir. 1980); Kaplan v. Int'l Alliance of Theatrical \& Stage Employees, 525 F.2d 1354, 1358 (9th Cir. 1975). But see Gay v. Waiters' \& Dairy Lunchmen's Union, Local 30, 694 F.2d 531, 542-46 (9th Cir. 1982) (adopting the free reviewability standard for findings of prima facie case) (discussed infra at notes 79-84 and accompanying text).

12 Silberhorn v. General Iron Works Co., 584 F.2d 970, 971 (10th Cir. 1978); Olson v. Philco-Ford, 531 F.2d 474, 476 (10th Cir. 1976); Williams v. Southern Union Gas Co., 529 F.2d 483, 488 (10th Cir. 1973), cert. denied, 429 U.S. 959 (1976); Woods v. North Am. Rockwell, 480 F.2d 644 (10th Cir. 1973).

${ }^{43}$ Causey v. Ford Motor Co., 516 F.2d 416, 420-21 (5th Cir. 1975). The Fifth Circuit has followed Causey on many occasions. See cases cited in Pullman-Standard, 456 U.S. at 285.

4 Detroit Police Officers Ass'n v. Young, 608 F.2d 671, 686 (6th Cir. 1979).

45 Stewart v. General Motors Corp., 542 F.2d 445, 449 (7th Cir. 1976), cert. denied, 433 U.S. 919 (1977); see also United States v. City of Chicago, 549 F.2d 415, 425 (7th Cir.), cert. denied, 434 U.S. 875 (1977) (elaborating the Seventh Circuit's adoption of the free reviewability standard). banc).

40 Strecker v. Grand Forks County Social Serv. Bd., 640 F.2d 96, 99 (8th Cir. 1980) (en

${ }^{47}$ Kinsey v. First Regional Sec., Inc., 557 F.2d 830, 835-36 (D.C. Cir. 1977).

48 516 F.2d 416 (5th Cir. 1975).

40 Id. at 421 .

so Sweeney v. Board of Trustees of Keene State College, 604 F.2d 106, 109 (1st Cir.), 
held not clearly erroneous. ${ }^{51}$ Yet, in the Fifth Circuit, a judgment resting upon a nearly identical finding ${ }^{52}$ led to a remand for further findings of subsidiary fact to enable the court of appeals to review freely the trial court's finding of no discrimination even though the appellate court conceded that the ultimate finding was not clearly erroneous. ${ }^{.3}$

2. Pullman-Standard v. Swint. Pullman-Standard v. Swint ${ }^{54}$ was a class action brought under Title VII by black employees challenging the legality of the seniority system at a steel plant operated by the petitioner. ${ }^{55}$ The district court found that the differences in the terms, conditions, and privileges of employment between minority and other employees resulting from the seniority system did not stem from racially-discriminatory intent. ${ }^{56}$ The Fifth Circuit reversed, relying not on rule 52(a), but on its prior holding in Causey that ultimate facts in Title VII cases are freely reviewable. ${ }^{.7}$ The Supreme Court reversed the Fifth Circuit and held the issue of discriminatory intent to be a "pure question of fact" reversible on appeal only if clearly erroneous. ${ }^{58}$

The Court's holding in Pullman-Standard is limited. Since the action challenged a seniority system, it was governed by a special provision of Title VII, section $703(\mathrm{~h})$. That section provides that the application of different terms, conditions, or privileges of employment, pursuant to a bona fide seniority system, is not an

cert. denied, 444 U.S. 1045 (1979).

s1 Id. at 114.

s2 DeAnda v. St. Joseph Hosp., 671 F.2d 850, 857 n.10 (5th Cir. 1982) ("The actions of Defendant in ... discharging Plaintiff were for legitimate nondiscriminatory reasons and were not motivated by any actions of Plaintiff protected by . . . Title VII . . . .").

s3 Id. at 858.

s4 456 U.S. at 273 (1982).

ss Id. at 275. Petitioners also alleged discrimination in job assignments and promotions as well as in the failure to post a list of changes in assignments publicly. Moreover, two charges of individual discrimination were brought. In granting certiorari, the Supreme Court declined to review these issues. Id. at 275 n.1.

${ }^{88}$ See id. at 275. Section 703(h) of Title VII, 42 U.S.C. $\S 2000 \mathrm{e}-2(\mathrm{~h})$ (1976), exempts seniority systems from the category of unlawful employment practices unless administered with discriminatory intent. Consequently, a disparate-impact claim is never sufficient to invalidate a seniority system. Trans World Airlines v. Hardison, 432 U.S. 63, 82 (1977).

${ }^{57}$ Swint v. Pullman-Standard, 624 F.2d 525, 533 n.6 (5th Cir. 1980), rev'd, 456 U.S. 273 (1982). The court of appeals quoted the formulation of the free reviewability standard set forth in Causey v. Ford Motor Co., 516 F.2d 416, 421 (5th Cir. 1975) (quoted supra at text accompanying note 49), although it attributed it to East v. Romine, Inc., 518 F.2d 332, 339 (5th Cir. 1975). Swint v. Pullman-Standard, 624 F.2d at 533 n.6. Justices Marshall and Blackmun dissented from the Court's conclusion that the Fifth Circuit had not applied the clearly erroneous standard. Pullman-Standard v. Swint, 456 U.S. at 295-304 (Marshall, J., dissenting).

ss 456 U.S. at $289-90$. 
unlawful employment practice unless such differences are "the result of an intention to discriminate." ing specifically in terms of "discriminatory intent under $\S 703(\mathrm{~h}) . "{ }^{\prime 60}$ The Court then noted carefully that discriminatory intent under section 703(h) is not a mixed question of law and fact, ${ }^{61}$ which it defined as a "question in which the historical facts are admitted or established, the rule of law is undisputed, and the issue is whether the facts satisfy the statutory standard, or to put it another way, whether the rule of law as applied to the established facts is or is not violated." "Discriminatory intent here," it emphasized, "means actual motive; it is not a legal presumption drawn from a factual showing of something less than actual motive."63

Since, under section 703(h), the defendant's discriminatory intent was a pure question of fact, the Court did not reach the applicability of rule 52(a) to mixed questions. ${ }^{64}$ Yet, the Court did observe that findings on mixed questions "in some cases may allow an appellate court to review the facts to see if they satisfy some legal concept of discriminatory intent." ${ }^{\text {"6s }}$ It also recognized that the Fifth Circuit's standard of free reviewability for findings of "ultimate facts" in Title VII cases might not be incorrect where "ultimate facts" are mixed questions of law and fact." Pullman-

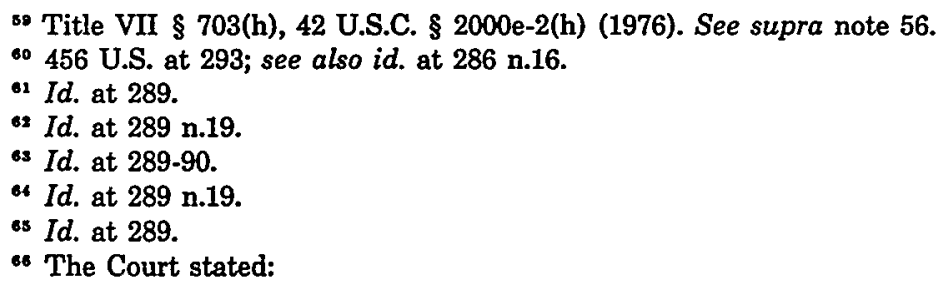

There is some indication in the opinions of the Court of Appeals for the Fifth Circuit (see n.15, supra) that the circuit rule with respect to 'ultimate facts' is only another way of stating a standard of review with respect to mixed questions of law and fact-the ultimate 'fact' is the statutory, legally determinative consideration (here, intentional discrimination) which is or is not satisfied by subsidiary facts admitted to be found by the trier of fact.

Id. at 286 n.16.

The Court did not cite any authority in support of its remark identifying issues of ultimate fact with mixed questions, but explicit case support does exist. In Washington v. Watkins, 655 F.2d 1346 (5th Cir. 1981), an appeal from denial of federal habeas corpus relief, the Fifth Circuit held that the petitioner's contention that he had not received effective assistance of counsel was a mixed question of law and fact, $i d$. at 1352, and noted that " $[t]$ he term 'mixed question of fact and law' seems to be used interchangeably in our prior decisions with the term 'ultimate fact' (as distinguished from 'subsidiary' or 'intermediate' facts)." Id. at 1352 n.4. The circuit court observed that mixed questions are not generally subject to rule 52(a), id. at 1352-53 (citing, inter alia, C. WriGht \& A. MnLER, supra note 24 , 2589 , at 753 ), and that, "as to the legal effect to be accorded to the district court's 
Standard, then, does not preclude treating Title VII findings of discrimination outside section $703(\mathrm{~h})$ as findings on mixed questions.

The disposition of many disparate-treatment actions, however, does depend upon "legal presumption[s of a defendant's discriminatory intent] drawn from a factual showing of something less than actual motive." ${ }^{\circ 7}$ In particular, disparate-treatment actions commonly are decided under the system of presumptions established by the Supreme Court in McDonnell Douglas. ${ }^{68}$ The next section of this comment will set out the McDonnell Douglas framework in detail and demonstrate that three of its presumptions involve mixed questions of law and fact.

\section{Pullman-Standard and the Elements of Proof of Disparate Treatment}

In Title VII suits challenging seniority plans on the basis of disparate treatment, plaintiffs are required, by virtue of section 703(h), to present direct proof of discriminatory intent. In most disparate-treatment actions, such direct proof is unnecessary since the plaintiffs can rely on the mode of proof developed in McDonnell Douglas Corp. v. Green ${ }^{69}$ and refined in a line of subsequent cases. The Court set forth this series of presumptions in the most recent case in that line, Texas Department of Community Affairs v. Burdine: ${ }^{70}$

First, the plaintiff has the burden of proving by the preponderance of the evidence a prima facie case of discrimination. Second, if the plaintiff succeeds in proving the prima facie case, the burden shifts to the defendant 'to articulate some legitimate, non-discriminatory reason for the [plaintiff's] rejection.' Third, should the defendant carry this burden, the plaintiff must then have an opportunity to prove by a preponderance of the evidence that the legitimate reasons offered by the defendant were not its true reasons, but were a pretext for

finding of basic historical fact, the court of appeals is free to substitute its own judgment for that of the district court," id. at 1353. In a footnote, the court cited six Fifth Circuit Title VII cases, including Causey, in support of its position. Id. at 1333 n.6.

${ }^{67}$ Pullman-Standard, 456 U.S. at 289-90.

68 See infra text accompanying notes 69-71.

69411 U.S. 792, 802-05 (1973).

${ }^{70} 450$ U.S. 248 (1981). See also Board of Trustees of Keene State College v. Sweeney, 439 U.S. 24 (1978); Furnco Constr. Co. v. Waters, 438 U.S. 567 (1978). 
discrimination. ${ }^{71}$

In most Title VII actions alleging discriminatory treatment, a court's finding as to the existence of discriminatory treatment will rest on the application of these presumptions. The determination of the proper standard of review for such findings depends on whether they are findings of fact or mixed findings. It is to that question that this comment now turns.

\section{A. Plaintiff's Prima Facie Case}

The question whether a Title VII plaintiff has established a prima facie case of discrimination qualifies as a mixed question under the Pullman-Standard test. In McDonnell Douglas the Supreme Court held that the plaintiff may establish a prima facie case of racial discrimination by showing

(i) that he belongs to a racial minority; (ii) that he applied and was qualified for a job for which the employer was seeking applicants; (iii) that, despite his qualifications, he was rejected; and (iv) that, after his rejection, the position remained open and the employer continued to seek applicants from persons of complainant's qualifications. ${ }^{72}$

If this formulation were the sole means of establishing a prima facie case, a mixed question would never arise. Once these four facts were proven, the legal conclusion that the plaintiff had established a prima facie case would follow ineluctably. However, the Court noted that the facts "necessarily will vary in Title VII cases" and that the McDonnell Douglas formula "is not necessarily applicable in every respect to differing factual situations."

In other cases, the Supreme Court has construed the fourfold showing set forth in McDonnell Douglas to be more illustrative than prescriptive. In International Brotherhood of Teamsters $v$. United States, ${ }^{74}$ the Court expressly rejected the contention that the McDonnell Douglas pattern was the only means of establishing a prima facie case. The importance of the former decision, said the Court, does not lie

in its specification of the discrete elements of proof there required but in its recognition of the general principle that any

${ }^{71}$ Id. at 252-53 (citations omitted).

72 McDonnell Douglas, 411 U.S. at 802.

${ }^{73}$ Id. at 802 n.13.

74431 U.S. 324 (1977). 
Title VII plaintiff must carry the initial burden of offering evidence adequate to create an inference that an employment decision was based on a discriminatory criterion illegal under the Act. ${ }^{75}$

The illustrative nature of the fourfold showing outlined in $\mathrm{McDon}$ nell Douglas was confirmed in Furnco Construction Corp. v. Waters $^{76}$ where the Court stated that McDonnell Douglas should be understood to stand for the general proposition that the plaintiff meets his initial burden by showing actions "from which one can infer, if such actions remain unexplained, that it is more likely than not that such actions were based on a discriminatory criterion illegal under the Act." 77

At the first level of the McDonnell Douglas system, a trial court must decide whether the historical facts as demonstrated by the plaintiff are legally sufficient to support a presumption of the defendant's intent to discriminate. As such, it requires the application of a legal standard to findings of fact, and hence is a mixed question as defined in Pullman-Standard. ${ }^{78}$

This analysis is supported by a circuit court opinion rendered four months after Pullman-Standard. In Gay v. Waiters' \& Dairy

75 Id. at 358.

76438 U.S. 567 (1978).

${ }^{77}$ Id. at 576 (quoting Teamsters v. United States, 431 U.S. at 358). The Court also declared that the method suggested in McDonnell Douglas for establishing a prima facie case "was never intended to be rigid, mechanized, or ritualistic." Id. at 577; see also Texas Dep't of Community Affairs v. Burdine, 450 U.S. 248, 254 n.7 (1981) (explaining that the prime facie case "denote[s] the establishment of a legally mandatory, rebuttable presumption" that the employer unlawfully discriminated against the employee). The Ninth Circuit has held in a number of cases that the plaintiff may make out a prima facie case even though one or more of the McDonnell Douglas criteria have not been met. E.g., O'Brien v. Sky Chiefs, Inc., 670 F.2d 864, 866-67 (9th Cir. 1982) (qualifications); Hagans v. Andrus, 651 F.2d 622, 624-26 (9th Cir. 1981) (job opening); McLean v. Phillips-Ramsey, Inc., 624 F.2d 70, 72 (9th Cir. 1980) (job opening).

78 See supra text at note 62 . Of course, within the limited scope of the fourfold showing set out in McDonnell Douglas, see supra text at note 72, a demonstration by the plaintiff of each required fact does not give rise to a mixed question. Once those four facts are proven by the plaintiff, a presumption of discrimination arises as a matter of law. As the law of disparate treatment actions grows, it may be expected that the legal standards governing an increasing number of fact patterns will become settled, thus diminishing the number of occasions where the mixed question of the sufficiency of the evidence to establish a prima facie showing of discrimination will be debatable. Oliver Wendell Holmes suggested that a similar development of legal standards had occurred to restrict the freedom of the jury in finding negligence. O.W. Holmes, The Common LAW 122-29 (1881). As Holmes pointed out, this reduction of mixed questions to pure questions of fact and law is the ultimate aim of any area governed by mixed questions, and the interest in fostering this development is a strong argument in favor of treating such debatable questions as mixed rather than as pure questions. See infra notes 107-115 and accompanying text. 
Lunchmen's Union Local $30{ }^{79}$ the Ninth Circuit adopted the free reviewability standard for a finding of the existence of a prima facie case, stating that application of the "clearly erroneous" standard is "inconsistent with the theoretical and functional role of the McDonnell Douglas burden-shifting procedure." ${ }^{80}$ The court distinguished two components of the presumptive prima facie case: "[t]he factual inquiry ... what facts has the plaintiff proved?" and the "legal inquiry: are these facts sufficient to support an inference of intentional discrimination?"в1 It concluded that the two components are "severable" for the purposes of appellate review, ${ }^{82}$ independently reviewed the district court's holding that the plaintiffs had not established a prima facie case, and affirmed the district court's judgment. ${ }^{83}$ Since the court's "legal inquiry" entails a determination of whether proven facts are legally sufficient to constitute a prima facie case, it falls within the Pullman-Standard definition of a mixed question. ${ }^{84}$

\section{B. The Defendant's Rebuttal}

The foregoing reasoning is equally applicable to findings that a defendant adequately rebutted the plaintiff's prima facie case. Once a prima facie case has been established, according to the Supreme Court's decision in Burdine, a defendant must introduce admissible evidence showing that the action was taken for a nondiscriminatory reason or judgment will be entered for the plaintiff. ${ }^{\mathrm{ss}}$ "The explanation provided must be legally sufficient to justify a judgment for the defendant," ${ }^{, 88}$ but the defendant need not prove that he or she was actually motivated by the reasons offered in rebuttal. ${ }^{87}$ The rebuttal need only "meet the plaintiff"s prima facie case by presenting a legitimate reason for the action and ... frame the factual issue with sufficient clarity"88 so that the plain-

79 694 F.2d 531 (9th Cir. 1982).

so Id. at 543. The court added that application of the "clearly erroneous" standard would also be "inconsistent with the Supreme Court's analysis and holding in [Furnco Constr. Corp. v. Waters, 438 U.S. 567 (1978)] and with the purpose of Rule 52(a)." Id. at 543-44.

si Id. at 543 n.10.

s2 Id.

ss Id. at $546-48$.

se supra text accompanying note 62 .

ss 450 U.S. at 254 ("If the trier of fact believes the plaintiff's evidence, and if the employer is silent in the face of the presumption, the court must enter judgment for the plaintiff because no issue of fact remains in the case." (footnote omitted)).

${ }^{86}$ Id. at 255.

37 Id. at 254.

ss Id. at $255-56$. 
tiff may thereafter prove it a pretext; the sufficiency of the defendant's evidence will be "evaluated by the extent to which it fulfills these functions." termine whether the defendant's showing is legally sufficient the court must apply a standard set by law. A finding that the defendant adequately rebutted the plaintiff's prima facie case thus also falls within Pullman-Standard's definition of a "mixed question of law and fact."90

\section{Plaintiff's Proof that the Rebuttal is a Pretext}

After rebuttal, the presumption of discrimination established by the plaintiff's prima facie showing "drops from the case," and the plaintiff must thereafter prove that the defendant acted with discriminatory intent. ${ }^{.2}$ Under the Supreme Court's formulation in Burdine, this may be done either "directly," by persuading the trier of fact of the defendant's discriminatory motive, or "indirectly," by proving the rebuttal "unworthy of credence."93

1. Direct Proof. A plaintiff who can prove by a preponderance of the evidence that the defendant was motivated by discriminatory animus may establish the defendant's liability independently of the McDonnell Douglas presumption. Such direct proof of discriminatory intent falls squarely within the holding of PullmanStandard, ${ }^{94}$ since it requires the plaintiff to establish the defendant's "actual motive" and no longer involves "a legal presumption to be drawn from a factual showing of something less than actual motive."95 Once the trial court finds plaintiff's proof sufficient to survive a motion to dismiss, and finds that discriminatory intent has or has not been established, Pullman-Standard dictates that this finding cannot be reversed on appeal unless clearly erroneous. ${ }^{96}$

88 Id. at 256.

${ }^{\circ}$ See supra text accompanying note 62.

${ }^{21}$ Burdine, 450 U.S. at 255 n.10. A rebuttal negates the legally mandated inference of discrimination established by the plaintiff's prima facie case, but does not preclude the trier of fact from considering the plaintiff's initial evidence on the issue of whether the defendant's explanation is a pretext. Id.

${ }^{82}$ Id. at 256. The plaintiff, of course, always retains "the ultimate burden of persuading the court that [he or she] has been the victim of intentional discrimination." Id.

9s $I d$.

${ }^{24}$ See supra notes 54-63 and accompanying text.

as Pullman-Standard, 456 U.S. at 289-90.

- Id. at 290; accord, Cline v. Roadway Express, Inc., 689 F.2d 481 (4th Cir. 1982). Cline arose under the Age Discrimination in Employment Act (ADEA), 29 U.S.C. $\S$ 621-34 (1976). In Cline, the Fourth Circuit, relying on Loeb v. Textron, Inc., 600 F.2d 1003 (1st Cir. 
Similarly, a plaintiff who does make use of the McDonnell Douglas presumption but who, after rebuttal, tries to show that the defendant acted with discriminatory animus, engages in a direct proof of the defendant's "actual motive," a pure question of fact. Under Pullman-Standard, a reviewing court must credit the resulting finding if not clearly erroneous. ${ }^{97}$

2. Indirect Proof. A plaintiff who seeks to prove discriminatory purpose need not demonstrate affirmatively that the defendant harbored discriminatory intent. Instead, the plaintiff may prove that intent indirectly by showing that the explanation offered by the defendant in rebuttal of the plaintiff's prima facie case is a mere pretext, "unworthy of credence." while it does not directly prove discriminatory intent, does revive the presumption of intent engendered by plaintiff's prima facie case. For example, if a member of a protected group is fired, his employer can effectively rebut the employee's prima facie case by introducing evidence of the employee's habitual tardiness; the employee might then establish that this explanation was but a pretext by showing that the employer commonly tolerated tardiness among persons not in the protected group. ${ }^{99}$

At first blush, such an indirect proof of discriminatory intent by a showing of pretext seems to involve a question of fact, namely, whether the justification given by the defendant is genuine. This characterization finds support in the Burdine Court's references to the question of the justification's credibility as a "factual issue"100 or "factual inquiry."101 Furthermore, the Court's

1979), held that the McDonnell Douglas system of proof may be employed to resolve questions of an employer's discriminatory motive that arise under the ADEA. 689 F.2d at 485 . On appeal from an adverse judgment, the defendant claimed that the district court had erroneously imposed on it a burden of proof to establish an affirmative defense rather than the lighter burden of production required by Burdine to dispel the plaintiff's prima facie case. Id. at 484. The court of appeals rejected this argument and held that the defendant had misunderstood the nature of plaintiff's proof. Discriminatory motive could, the court stated, be directly proved "without resort to any special judicially created presumptions or inferences," and if so proved, the defendant's countervailing evidence "is simply evidence offered, as in any context, to rebut proof of an essential element of any claim." Id. at 485. Accordingly, the court affirmed the judgment in relevant part after finding the trial court's holding not clearly erroneous. Id.

17 Pullman-Standard, 456 U.S. at 289-90.

98 Burdine, 450 U.S. at 256.

9 See McDonnell Douglas, 411 U.S. at 804 (employer could justifiably refuse to rehire someone who engaged in disruptive activity but only if this criterion is applied alike to members of all races).

100 Burdine, 450 U.S. at 255-56.

101 Id. at 255. 
alternative formulation of the plaintiff's task as "showing that the employer's proffered explanation is unworthy of credence"102 suggests the weighing of competing evidence traditionally within the province of the trier of fact. ${ }^{103}$

Upon closer examination, however, indirect proof of discriminatory intent by a showing that the employer's justification lacks credibility proves to be a mixed question of law and fact. Neither the sufficiency of defendant's rebuttal nor the plaintiff's showing that the reasons set forth in the rebuttal are unworthy of credence compels the court to determine the defendant's actual reasons for rejecting the plaintiff. ${ }^{104}$ An indirect proof of pretext requires the plaintiff to demonstrate that the nondiscriminatory reasons offered in the defendant's rebuttal are, in light of facts adduced by the plaintiff, legally insufficient to rebut the presumption of discriminatory intent created by the plaintiff's prima facie showing. The plaintiff must show not that the defendant's reasons are not to be credited, i.e., that they were not in fact his reasons for rejecting the plaintiff, but that they are not credible, i.e., that they are not sufficient to rebut the prima facie presumption that an employer who discriminates probably intends to do so. As such, the plaintiff's showing of pretext involves the application of the same legal standard of credibility to the defendant's proffered reasons as does assessing its legal sufficiency as a rebuttal, ${ }^{105}$ though now in light of the plaintiff's evidence concerning the defendant's employment practices. Therefore, a determination of discriminatory treatment based on a plaintiff's indirect proof of pretext involves a mixed question under Pullman-Standard. ${ }^{108}$

\section{Interests Implicated By The Choice of Standards of Review In Title VII Actions}

The critical difference between the "clearly erroneous" and "free reviewability" standards is the process that they compel an appellate court to follow. While the "clearly erroneous" standard obviously more strongly favors affirmances, neither standard prevents a disingenuous reviewing court from substituting its judg-

102 Id. at 256.

${ }^{103}$ See supra notes $27-28$ and accompanying text.

104 See Burdine at 254 (rebuttal); id. at 256 (plaintiff's showing of pretext only requires demonstrating that defendant's "proffered reason was not the true one").

${ }^{105}$ See supra notes 85-90 and accompanying text.

${ }^{106}$ See supra text at note 62. 
ment for that of the trial court. ${ }^{107}$ This section argues that free appellate review of mixed questions of law and fact in disparatetreatment actions is consistent with the purpose of rule 52(a) and with cases in analogous areas of the law. Moreover, it contends that free review of such questions will better serve the goal of fair, rapid, and uniform disposition of claims than will review under the clearly erroneous standard.

Title VII litigation imposes a considerable burden on the federal judiciary. ${ }^{108}$ Free review of mixed questions of law and fact will ease this burden and provide lower courts with greater guidance. In order for a court employing a free reviewability standard to dispose of challenges to findings of mixed questions of law and fact, it must decide whether the historical facts found by the trial court have the legal significance that the district court attributed to them. If the same set of facts occurs in a subsequent case, the appellate court's former decision will have settled whether the facts satisfy the applicable legal standard. Appellate review under the clearly erroneous standard, however, does not necessarily establish that a given set of facts satisfies the relevant legal standards; affirming a finding as not clearly erroneous does not require trial courts in future cases to make the same finding on the same set of facts.

In Gay v. Waiters' \& Dairy Lunchmen's Union, Local 30, for example, the district court held that the plaintiffs failed to establish a prima facie case since they did not prove that they had applied for employment "at the time a job opening existed." ${ }^{109} \mathrm{Had}$ the court of appeals merely affirmed this holding as not clearly erroneous, the affirmance would have had little precedential value in subsequent disparate-treatment actions. By affirming after free review, the court compelled all district courts of the Ninth Circuit to hold in the future that no prima facie case of discriminatory refusal to hire may be made in the absence of proof of a specific job opening. Gay thus establishes that the job-opening requirement of McDonnell Douglas cannot be dispensed with and that proof of

${ }^{107}$ See, e.g., Coble v. Hot Springs School Dist. No. 6, 682 F.2d 721 (8th Cir. 1982) where the appellate court, after reviewing the record, determined that the trial court's findings as to rebuttal and pretext were clearly erroneous. Id. at 726-28. This case is discussed and criticized infra notes 111-15 and accompanying text.

${ }^{108}$ In 1980, 5,017 employment discrimination actions were commenced in the United States district courts; in 1979, 5,477 were filed. Administrative Orfice of the UNITED States Courts, 1980 Annual Report of the DrRector 70.

${ }^{109}$ Gay v. Waiters' \& Dairy Lunchmen's Union, Local 30, 694 F.2d 531, 546 (9th Cir. 1982). 
the general availability of jobs is not an adequate substitute. ${ }^{110}$ Free review of mixed questions, by yielding decisions which are necessarily precedential, will facilitate the uniform disposition of Title VII cases.

The freely reviewable standard also prevents unprincipled determinations by appellate courts. In Coble v. Hot Springs School District No. $6,{ }^{111}$ for example, two female teachers brought individual and class claims alleging sex discrimination in the defendant school district's promotion practices. The district court held that plaintiffs had failed to prove defendant's rebuttal of their individual claims a pretext. ${ }^{112}$ The court of appeals reversed under the clearly erroneous standard and remanded for award of appropriate relief. ${ }^{113}$ Discussing the evidence that led it to this conclusion, the court characterized the facts in the plaintiff's favor as certainties but those in the defendant's favor as doubtful. ${ }^{114}$ Ultimately, the court of appeals appears simply to have substituted its evaluation of the facts of an admittedly close case for that of the district court. ${ }^{115}$ If the court, following the present analysis, had reviewed the lower court's determination freely, it could not have reversed without setting forth either some deficiency in the defendant's evidence or some particular facts proved by the plaintiff that accounted for its decision. Such a decision would compel a similar result in subsequent actions. By relying on the "clearly erroneous" standard, however, the court of appeals confined the precedential value of its opinion to its particular facts. Consequently, the district courts of the Eighth Circuit, after Coble, are left with an impression that their court of appeals favors Title VII plaintiffs but

110 Id. at $547-48$.

111682 F.2d 721 (8th Cir. 1982).

112 Id. at 723.

${ }^{113}$ Id. at 726, 728-29.

114 E.g., id. at 726 ("The evidence showed that superintendent Meeks unfairly emphasized Coble's family responsibilities and used essentially subjective promotion criteria in selecting the director of the teachers center."); $i d$. at 727 ("Coble presented substantially unrebutted evidence showing that the superintendent made the employment decision largely on the basis of a sexual stereotype. Coble also presented evidence . . . showing that the superintendent may have undervalued her workshop experience . . ."): id. at $727 \mathrm{n} .2$ ("It is arguable that the superintendent may have made the employment decision on the basis of marital or parental status."); $i d$. at 727 n.3 ("The record indicates that the superintendent and the assistant superintendent were less familiar with Coble's workshop experience."); id. at 728-29 ("[E]vidence discredited the validity of the French certification requirement.").

115 See $i d$. at 728 ("We have carefully reviewed the record and conclude that the district court's finding ... is clearly erroneous. There was persuasive evidence of preselection."). 
no guidance as to which future plaintiffs will be similarly favored.

\section{Conclusion}

In Title VII disparate-treatment actions where, at the close of the plaintiff's case-in-chief, the plaintiff's evidence would not withstand a motion to dismiss in the absence of legal presumptions set forth in McDonnell Douglas and its progeny, Pullman-Standard $v$. Swint does not compel courts of appeal to review the trial court's findings on prima facie case, rebuttal, or pretextuality under the clearly erroneous standard of rule 52(a). Free review of such questions will foster uniformity of application of the general congressional prohibition of discrimination in employment and create an incentive for trial and appellate courts to confine themselves to the functions for which they are best suited.

George G. Nelson 